\title{
Maquiladoras: An Important Asset For Mexico's Economy
}

Joseph Heinzman Jr., Hodges University

Gian Marco Valentini, Hodges University

\begin{abstract}
Maquiladoras are foreign-owned companies located for the most part along the California and Texas border in Mexico. Because of particular customs treatments, very low wages compared to wages in the United States, and the geographic proximity to the United States, maquiladoras represent a strong attraction for American investors and corporations. Maquiladoras are also an important asset for the Mexican economy and are accountable for about 45\% of Mexico's total exports. Finally, maquiladoras are an important source of job opportunities for the Mexican workforce today and in the future.
\end{abstract}

\section{MAQUILADORAS: HISTORIC INTRODUCTION}

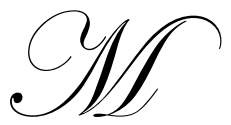

aquiladoras are manufacturing firms, operating in Mexico under special customs treatments. Because of this special customs regulation, American companies can send raw materials, equipments, and machineries to maquiladoras, without paying any import duty. Once in Mexico, raw materials and other supplies are processed and assembled. Finally, the finished goods are sent back to the United States or to foreign markets (The City of San Diego, 2007).

The maquiladora program, also known as the Mexico Border Industrialization Program (BIP), started in 1965, about 1 year after the termination of the American Bracero Program, a plan established by the American government to attract Mexican workers in the agricultural sector. With the Mexico Border Industrialization Program, the Mexican government tried to reach the two following goals:

- $\quad$ Persuade foreign investors to build manufacturing companies in the country.

- Give a job to about 4 million Mexicans who were returning back to their own country after the termination of the American Bracero Program.

In other words, the BIP can be viewed as the extension of the American Bracero Program to the industrial sector (Wear, 2002). Initially, the BIP did not obtain the success that the Mexican government was expecting. Mexican labor wages were still too high to be attractive and competitive. Initially, European and American investors opened only a few factories in Mexico (Beaumier, 1990).

The situation changed drastically in 1982 when the Mexican currency experienced a strong devaluation. As a consequence of devaluation wages dropped considerably, and the BIP registered a remarkable growth. Table 1 shows the growth of the maquiladora program between 1965 and 1986. Mexico's share of United States imports increased considerably after 1965, when Mexico's share of United States imports rose from a simple 0.52\% in 1965, the year when the BIP was launched, to 17.67\% in 1986 (Beaumier, 1990). 
Table 1

\begin{tabular}{|c|c|c|}
\hline Year & Total Import (million dollars) & Mexico's Share of US import \\
\hline 1965 & 577 & $0.52 \%$ \\
\hline 1970 & 2,208 & $9.52 \%$ \\
\hline 1976 & 5,722 & $19.84 \%$ \\
\hline 1980 & 14,017 & $16.66 \%$ \\
\hline 1986 & 36,497 & $17.67 \%$ \\
\hline
\end{tabular}

\section{MAQUILADORAS: CUSTOMS TREATMENTS AND ORGANIZATION}

As already stated above, a maquiladora is a foreign-owned company located in Mexico. In these plants, materials and supplies are processed, and the final products are sent back to the United States or to foreign markets (VanZante, 1991).

Maquiladoras benefit from a special customs treatment. Specifically, supplies, materials, and equipment imported to a maquiladora from a North American Free Trade Agreement (NAFTA) country are not subjected to customs duties in Mexico. In addition, resources imported from non-NAFTA countries are still exempt from Mexican import duties, if the final products are exported to a non-NAFTA market. Non-NAFTA originating supplies, equipments, and materials are subjected to Mexican import duties, if the final goods are successively exported to a NAFTA market (Suinaga, 2007).

There are basically no restrictions on the types of products that can be manufactured in a maquiladora. The only limitations regard the production of weapons and the use of radioactive materials. In this case, investors must attain a special authorization that can be obtained from the Secretariat of Defense and from the Mexican Nuclear Regulatory Agency (Baz, n.d.).

There are three different ways; firms can enter the maquiladora program: shelter operations, $100 \%$ ownership, and subcontracting.

- With shelter operations, a foreign company sends a production technician to a maquiladora. This specialist controls the production process and guarantees that the products manufactured in the maquiladora match the quality and quantity requirements of the parent company. The shelter operations option is the safest solution a company can opt for, when entering into the maquiladora program. In fact, using this option, the foreign-owned company does not have to worry about Mexican labor laws, transportation of goods, permits and the hiring process (The City of San Diego, 2007).

- The $100 \%$ ownership option is usually preferred when the products manufactured are complex and sophisticated. In this case, a foreign company sends its own managers to Mexico to manage the maquiladora. In other words, the Mexican maquiladora can be considered an extension of the parent firm that uses the maquiladora to process and assemble raw materials (City of San Diego, 2007).

- With the subcontractor option, a company signs a formal agreement with a maquiladora. The advantage of this option is that the foreign firm does not get involved in any part of the production and management process. In addition to that, the foreign firm does not send its managers to Mexico. The maquiladora imports raw materials and then, it sends the products back to the other party, respecting the terms of the agreement previously signed. Furthermore, the maquiladora is responsible for the quality of the products produced. In other words, with this option, the maquiladora works as a subcontractor and it receives payments on the basis of the products manufactured (Morales, 1994).

\section{THE IMPACT OF MAQUILADORAS ON THE MEXICAN ECONOMY}

There is no doubt that maquiladoras represent an important aspect of the Mexican economy. In fact, the strategic proximity to the United States allows maquiladoras to introduce the products manufactured into the American markets in real time. In addition to that, Mexican labor wages are much lower than both the American 
wages and the wages of many other countries. Low Mexican wages can be considered responsible of the great success obtained by the maquiladoras.

Chart 1 indicates how the maquiladora industry and its impact on the Mexican economy by showing the salaries received by Mexican workers employed in maquiladoras during the past few years and that the salaries received by maquiladora employees are extremely low. In particular, maquiladora wages are much lower than American wages. As the graph shows, between 2000 and 2005, the maquiladora wages were below $2 \$$ per hour, less than half of the minimum wage received by American workers employed in similar industrial sectors. In addition, it is important to observe that maquiladora wages did not increase in total between 2000 and 2005. Wages actually registered a sharp decline. That is why, many American companies entered into the maquiladora program in Mexico, in the attempt to reduce their production costs (Maquila Portal, 2007).

Chart 1

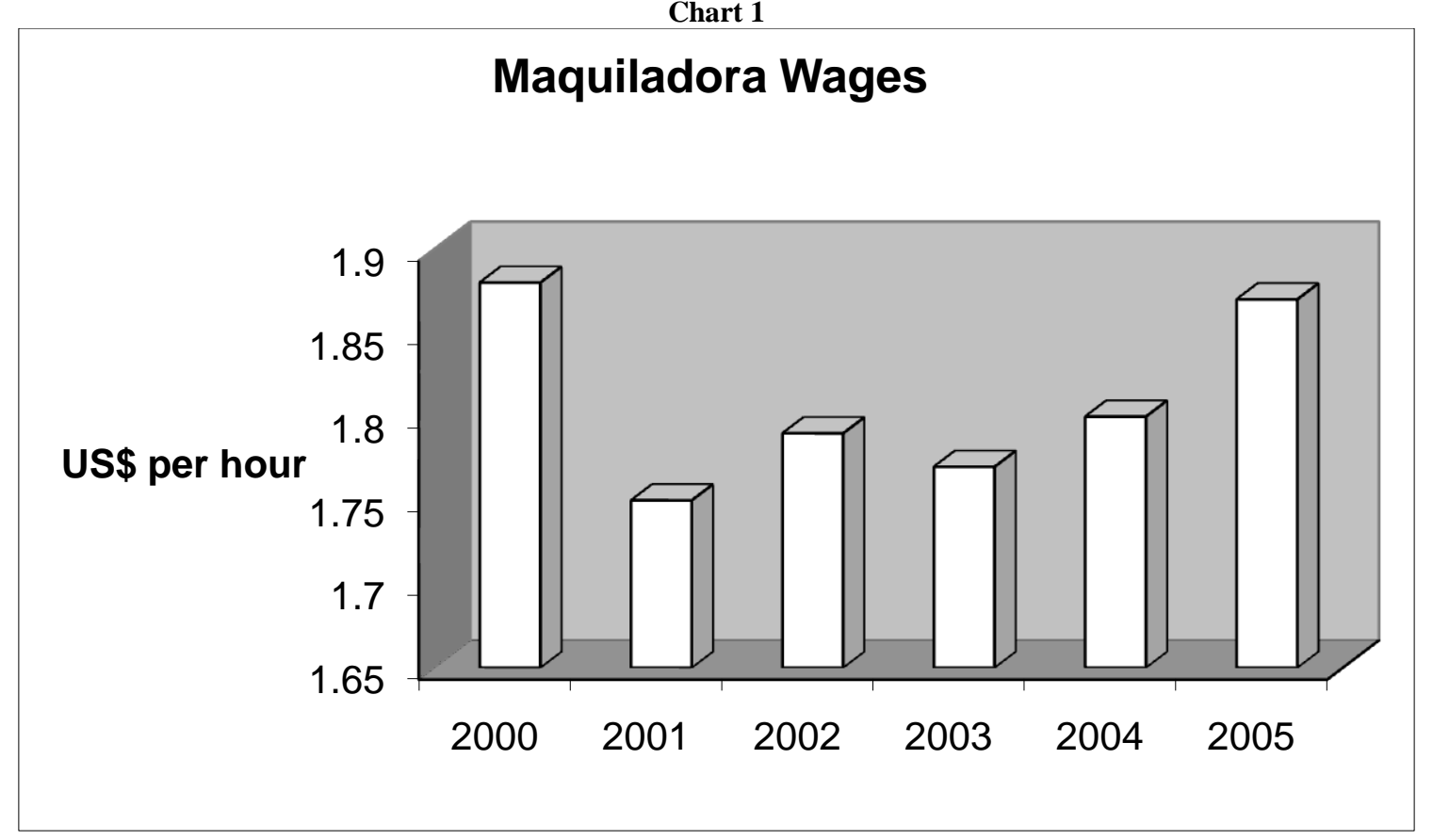

One of the major results of maquiladoras on the Mexico's economy is the creation of jobs for the Mexican workforce. In fact, it is possible to classify the maquiladora industry in eight different sectors: furniture, electrics and electronics, transportation, textile, chemical, machinery, services, and others. Chart 2 shows the share of maquiladora employment by sector (Federal Reserve Bank of Dallas, 2007). 


\section{Chart 2}

\section{Share per Employment by Sector in 2006}

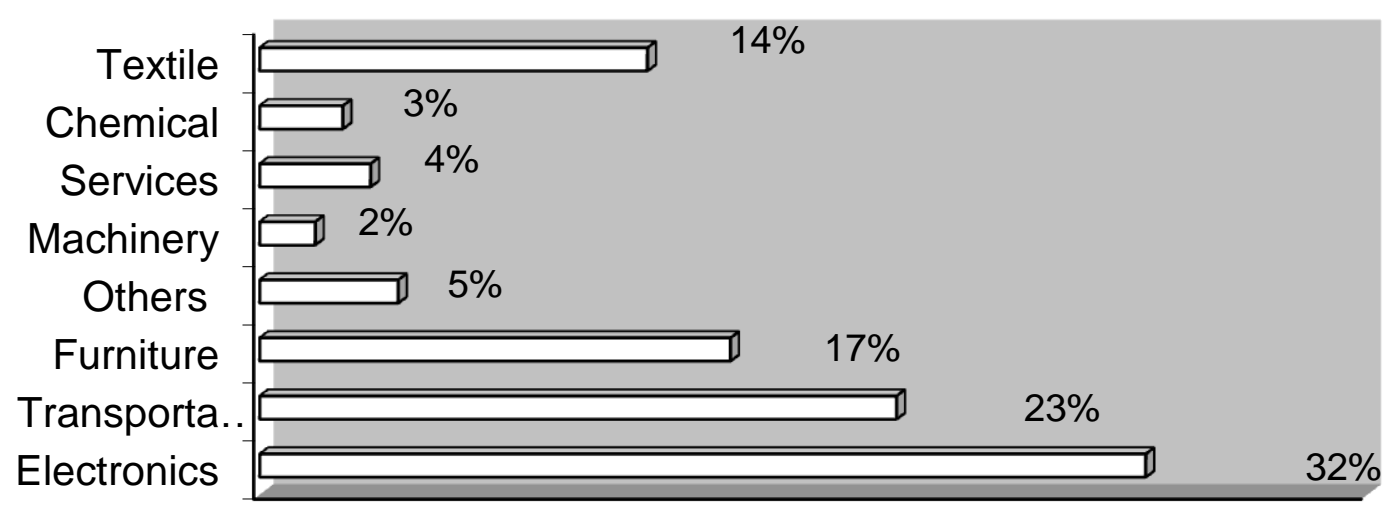

From the analysis of Chart 2, it is possible to notice that transportation, electronics, and furniture are the most important sectors of the entire industry. In particular, they account for about the $70 \%$ of the workers employed in maquiladoras (Federal Reserve Bank of Dallas, 2007). Also the textile sector is extremely important as it accounts for $14 \%$ of the level of employment. However, in the past few years, because of the competition with China and Bangladesh, the textile sector has been experiencing a contraction of the production, and therefore, a reduction of the number of people employed (Federal Reserve Bank of Dallas, 2007).

Since the beginning of the BIP in 1964, the number of employees working in maquiladoras increased considerably (INEGI, 2007a). Chart 3 shows the variation of maquiladora workers since 1996 (INEGI, 2007a).

Chart 3

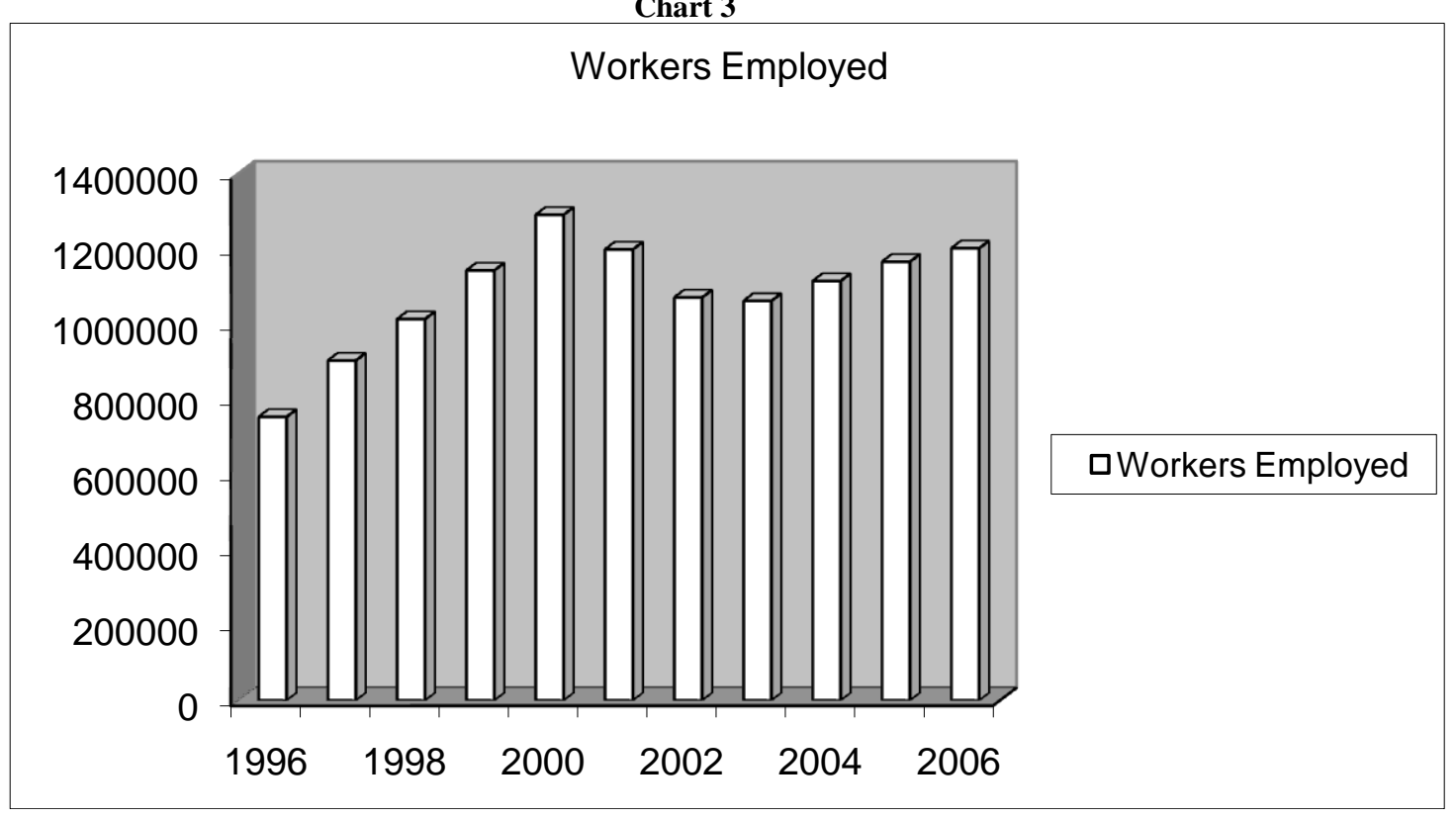


It is easy to notice the remarkable increase of people working in maquiladoras over the past few years. In particular, the level of employment reached its peak in 2000. Successively, the number of workers employed in maquiladoras experienced a small contraction probably due to problems affecting the United States' economy and the competition with China, especially in the textile sector (INEGI, 2007a). Furthermore, Chart 4 shows the variation in percentage of the workers in the maquiladora industry (INEGI, 2007a).

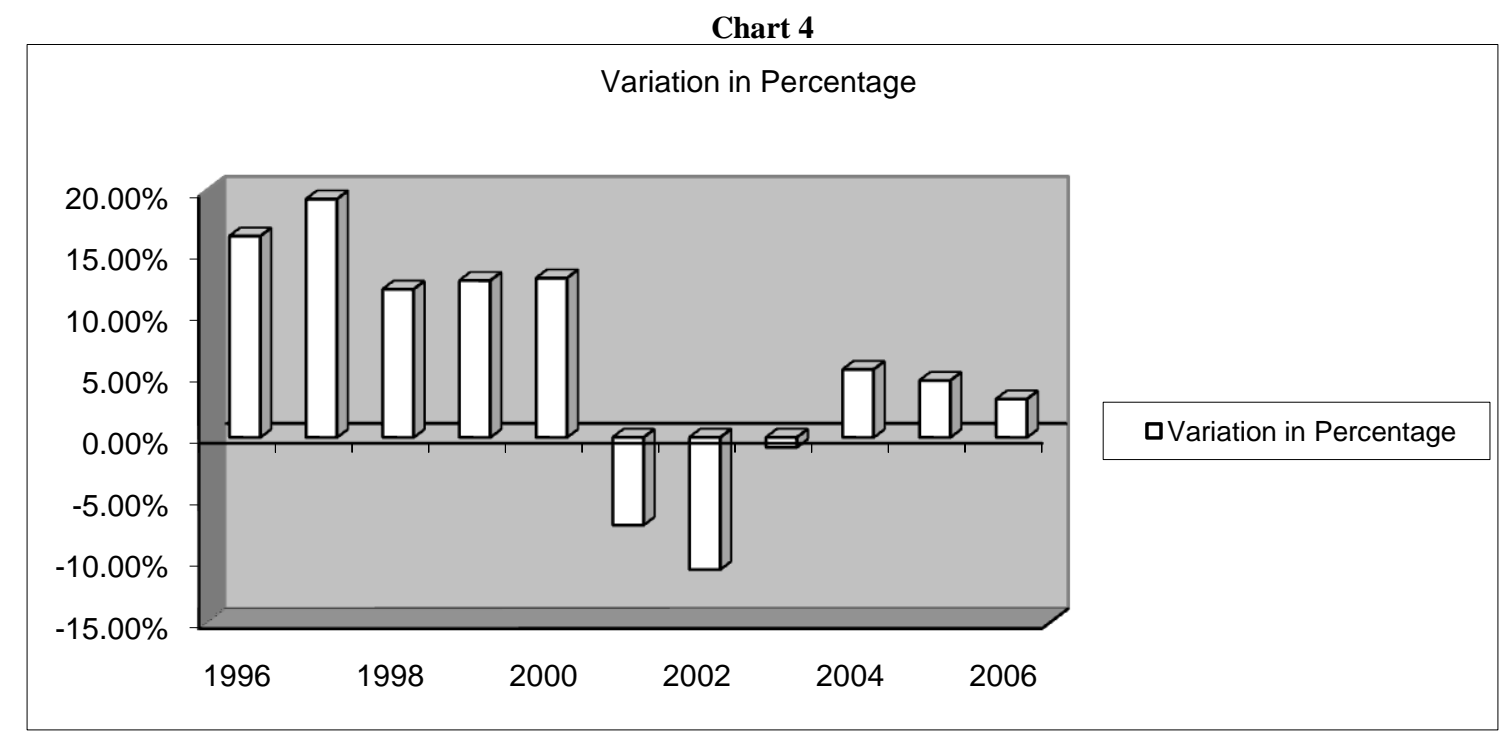

It is possible to observe that the employment rate dropped between 2000 and 2002. As stated above, the contraction was due to the problems that the American economy was facing. However, in the last few years, the employment rate raised again, showing that the maquiladora industry is still very active and competitive (INEGI, 2007a). It is also interesting to study which industry sector registered the highest percentage gain and the highest loss of jobs. Chart 5 shows the development of the maquiladora employment by sector in the past few years (INEGI, 2007a.).

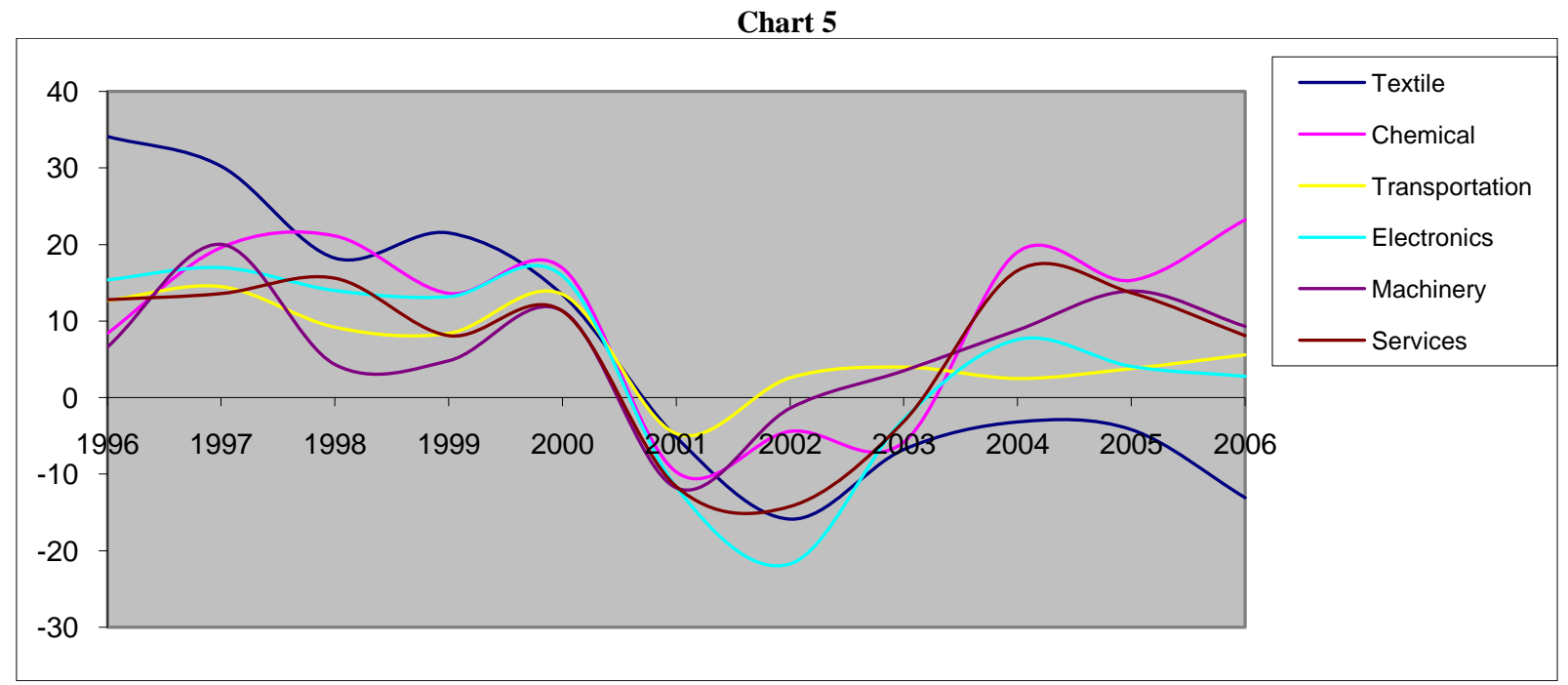

From the analysis of the information shown in the chart 5 , it is possible to notice that the textile sector registered the most significant decline of employment. This contraction is probably due to the competition with China, Bangladesh, and other Asian countries that are becoming more competitive in the international markets. In 
the remaining sectors, the employment rate has been constantly growing over the first few years of the new millennium. Such important data can be interpreted as a signal of vitality of the maquiladora industry after the drastic reduction of workers of the beginning of 2000. In particular, both the chemical and transportation sectors registered the most remarkable increase of employment in the past few years (INEGI, 2007b).

The creation of job opportunity is not the only impact that maquiladoras have in Mexico. Products manufactured in maquiladoras are exported in the United States and in other international markets thus improving Mexico's balance of payments. This movement of goods from Mexico to other countries generates a huge amount of money that flows into Mexico's economy. Several studies, conducted by the Federal Reserve Bank of Dallas, show that maquiladoras account for about half of the Mexican exports. In particular, a recent investigation indicates that, in 2006, the maquiladoras were responsible for about the $46 \%$ of the total Mexico's exports (Federal Reserve Bank of Dallas, 2007).

It is necessary to take in consideration the maquiladora's gross production in order to have a better understanding of the important role that maquiladoras play in the Mexican economy. Chart 6 shows the maquiladora gross production in the past few years. This indicates a positive trend of the maquiladora's gross production during the past six years. In particular, in 2005, the gross production reached 105.4 million dollars (Maquila Portal, 2007). This trend, in association with the increase of the employment rate, supports a prediction that maquiladoras will probably continue to experience a positive growth in the near future.

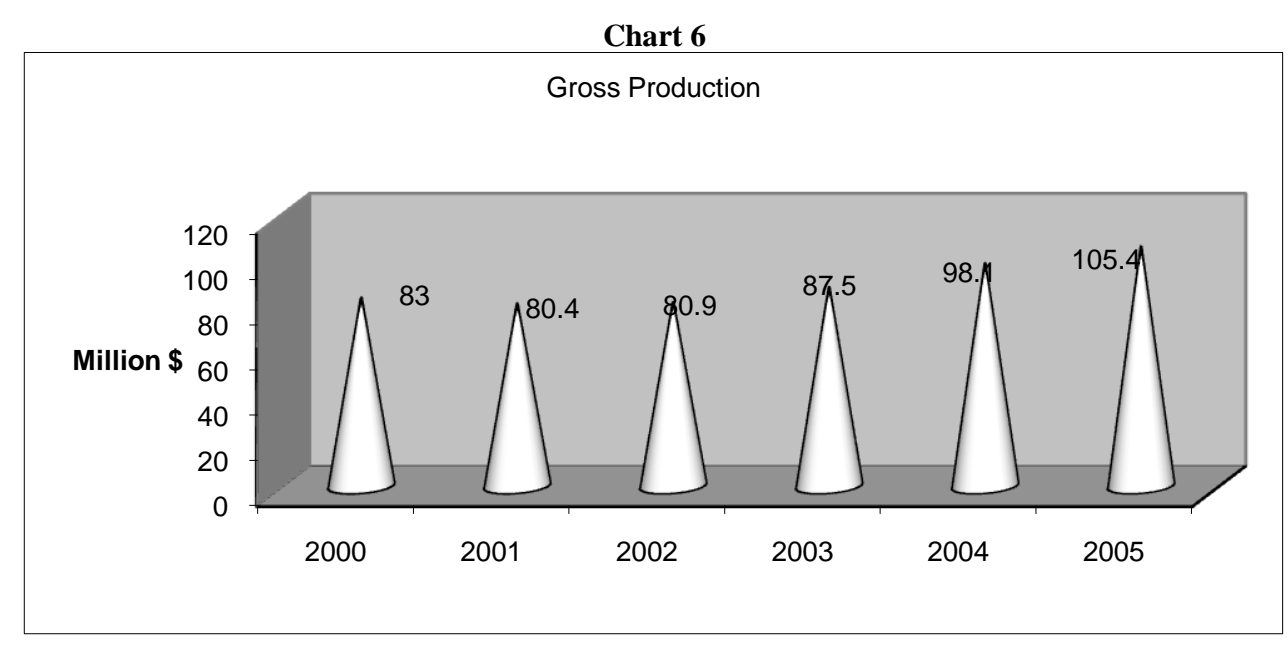

Another important consideration is the amount of United States dollars that the maquiladora industry generates with its exports. This information is particularly important when compared with the amount of money that non-maquiladora companies are able to create in Mexico. Chart 7 compares the exports of maquiladoras and nonmaquiladora firms (INEGI 2007c). 


\section{Chart 7}

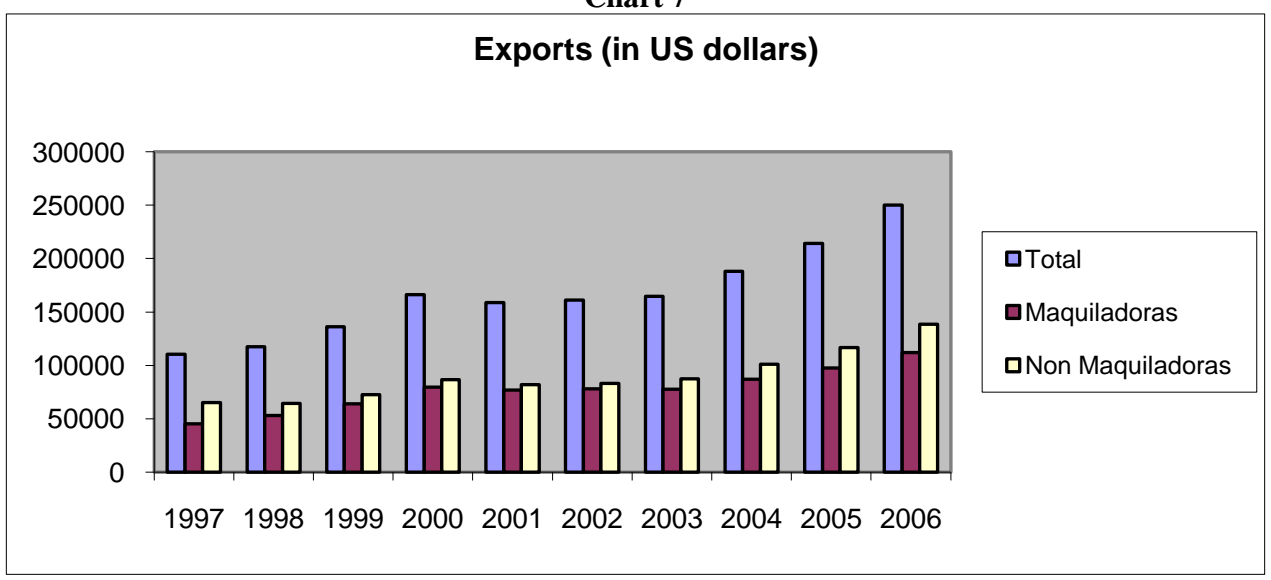

The data in Chart 7 indicates that since 1997 the maquiladora industry accounts for about the $50 \%$ of the Mexican national level of exports. In particular, during the past 10 years, the maquiladora exports increased constantly (INEGI, 2007c).

\section{LIMITATION OF THE STUDY}

This study did not predict the future of the maquiladora production based on statistically available information but the growth trend is fairly steady and there is no indication of any rapid growth in the near future. It is likely that slow stead growth in the chemical, electronics, and service areas will prevail.

\section{FUTURE STUDY}

The government of Mexico needs to address the future growth and direction of the maquiladora industry. Low cost maquiladora manufacturing in the automotive and aerospace industry, products requiring quick reaction production and delivery, and physically large products are on the rise and the future potential lies in these arenas. Products that are cheap to manufacture, inexpensive to transport, and have steady production and delivery requirements will be sent to China by US manufacturers rather than to Mexico. The political environment requires a close scrutiny by academia.

\section{CONCLUSION}

Maquiladoras are a very important part of the Mexican economy. Low wages, the strategic geographic proximity with the American markets, and the less problematic linguistic and cultural barriers contribute to the success obtained by maquiladoras.

From the information collected and explored in this paper it is possible to conclude that the maquiladora industry has been experiencing a positive growth since the depreciation of the Mexican currency. In fact, the employment rate in the maquiladora industry has been growing since the crisis of the beginning of the 2000 . In addition, maquiladoras are able to generate an amount of United States dollars in exports that accounts for about the $50 \%$ of the national total exports. All of that supports the conclusion that maquiladoras still have great possibilities for sustained future growth of the Mexican economy.

However, as Chart 5 shows, the textile sector is in a period of crisis. In fact, its level of production and its level of employment registered a serious contraction in the past few years. The reasons behind this problem are probably strictly associated with the introduction into the American market of products manufactured in China and Bangladesh, countries in which labor wages are very low. So far, only the textile sector seems to feel the effects of 
the competition. However, it would be a mistake to believe that the impact of cheap Chinese labor will not be experienced in other sectors of the maquiladora industry in the near future.

The future rise of labor rates in Mexico will be greatly determined by the continued success of the maquiladoras and as a result, the standard of living will be directly affected for the Mexican workforce. The ease of movement of goods between the US and Mexico will be a significant variable in this path forward for Mexico. The health of the US economy will continue to be related to the rise of the economy of Mexico and other trade partners where US companies locate production facilities and requirements. However, the long haul favors a rising Mexican economy based significantly on the predicted continued success of the maquiladoras.

\section{REFERENCES}

1. $\quad$ Baz, A. (n.d.). What is a maquiladora? Retrieved March 4, 2007, from http://www.udel.edu/leipzig/texts2/vox128.htm

2. Beaumier, G. (1990). Free trade in North America: the maquiladora factor. Retrieved March 4, 2007, from http://dsp-psd.pwgsc.gc.ca/Collection-R/LoPBdP/BP/bp247-e.htm\# (2)

3. Federal Reserve Bank of Dallas (2007). Maquiladora industry update. Retrieved March 25, 2007, from http://www.dallasfed.org/data/data/maq-charts.pdf

4. INEGI, (2007a). Personal ocupado en la industria maquiladora de exportacion segun tipo de ocupacion. Retrieved March 25, 2007, from http://www.inegi.gob.mx/est/contenidos/espanol/rutinas/ept.asp?t=emp75\&c=1811

5. INEGI, (2007b). Personal ocupado en la industria maquiladora de exportacion segun grupos de productos procesado. Retrieved March 25, 2007, from http://www.inegi.gob.mx/est/contenidos/espanol/rutinas/ept.asp?t=emp79\&c=5511

6. INEGI, (2007c). Retrieved March 25, 2007, from http://www.inegi.gob.mx/est/contenidos/espanol/rutinas/ept.asp?t=ext11\&c=1148

7. Maquila Portal (2007). Maquila overview. Retrieved March 31, 2007, Web site: http://www.maquilaportal.com/Visitors_Site/nav21.htm

8. Morales, G. (1994). An overview on the maquiladora program. Retrieved March 4, 2007, from http://www.dol.gov/ilab/media/reports/nao/maquilad.htm

9. Suinaga, (n.d.). Mexico's maquiladora system. Retrieved March 4, 2007, from http://www.lawyersworldwide.com/content/Mexico's\%20Maquiladoras\%20System.pdf

10. The city of San Diego (2007). Maquiladoras/twin plants. Retrieved March 4, 2007, from http://www.sandiego.gov/economic-development/international/maquilad.shtml

11. VanZante, N. (1991). Maquiladoras: should US companies run for the border? The CPA Journal, Retrieved March 4, 2007, from http://www.nysscpa.org/cpajournal/old/11583331.htm

12. Wear, A (2002). Class and Poverty in the Maquila Zone. International Socialist Review, Retrieved March 4, 2007, from http://www.thirdworldtraveler.com/Mexico/Class_Poverty_MaquilaZone.html 